\title{
The Fellowship of the Ring Test : DNAqua-Net WG2 initiative to compare diatom metabarcoding protocols used in routine freshwater biomonitoring for standardisation
}

\begin{abstract}
Valentin Vasselon‡, Éva Ács§, Salomé Almeidal, Karl Andreeף, Laure Apothéloz-Perret-Genti"\#, Bonnie Bailet $^{\not \prime}$, Ana Baricevic", Kevin Beentjes", Juliane Bettig^, Agnès Bouchez" ", Camilla Capelli?, Cécile Chardon`, Mónika Duleba§, Tina Elersek ${ }^{\varsigma}$, Clémence Genthon ${ }^{\S}$, Melanie Hurtz ${ }^{\ell}$, Louis Jacas ${ }^{\vee}$, Maria Kahlert ${ }^{\natural}$, Martyn Kelly ${ }^{P}$, Matthieu Lewis ${ }^{A}$, Jan N. Macher", Federica Mauri', Marina Moletta-Denat ${ }^{\Phi}$, Andreia Mortágua ${ }^{z}$, Jan Pawlowski ${ }^{F}$, Javier Pérez Burilloף, Martin Pfannkuchen ${ }^{\mp}$, Erik Pilgrim ${ }^{\mathbb{N}}$,

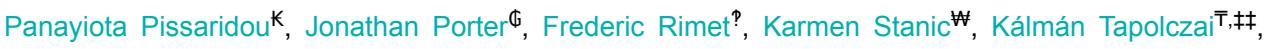
Susanna Theroux§§, Rosa Trobajoll, Berry van der Hoorn", Marlen Ines Vasquez Hadjilyrak, Kerry Walsh $^{\Phi}$, David Wanless $\$ \S$, Jonathan Warren ${ }^{\Phi}$, Jonas Zimmermann`, Maša Zupančič
\end{abstract}

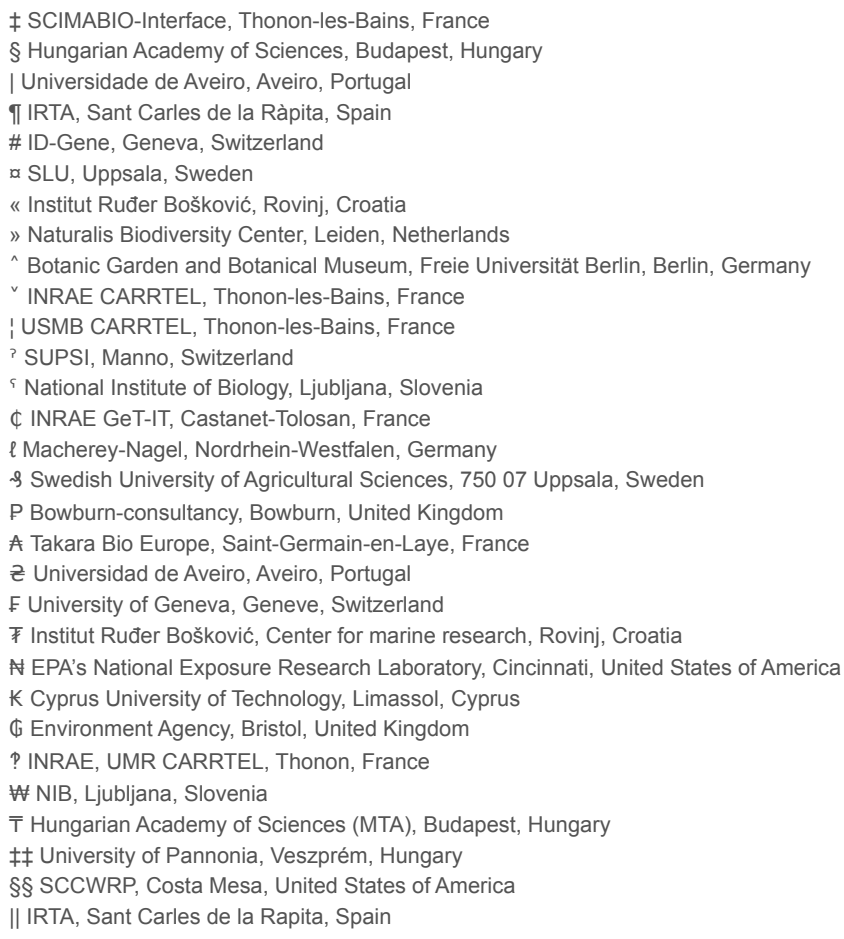


Corresponding author: Valentin Vasselon (valentin.vasselon@scimabio-interface.fr)

Received: 26 Feb 2021 | Published: 04 Mar 2021

Citation: Vasselon V, Ács É, Almeida S, Andree K, Apothéloz-Perret-Gentil L, Bailet B, Baricevic A, Beentjes K, Bettig J, Bouchez A, Capelli C, Chardon C, Duleba M, Elersek T, Genthon C, Hurtz M, Jacas L, Kahlert M, Kelly M, Lewis M, Macher JN, Mauri F, Moletta-Denat M, Mortágua A, Pawlowski J, Pérez Burillo J, Pfannkuchen M, Pilgrim E, Pissaridou P, Porter J, Rimet F, Stanic K, Tapolczai K, Theroux S, Trobajo R, van der Hoorn B, Vasquez Hadjilyra MI, Walsh K, Wanless D, Warren J, Zimmermann J, Zupančič M (2021) The Fellowship of the Ring Test: DNAqua-Net WG2 initiative to compare diatom metabarcoding protocols used in routine freshwater biomonitoring for standardisation. ARPHA Conference Abstracts 4: e65142.

https://doi.org/10.3897/aca.4.e65142

\section{Abstract}

During the past decade genetic approaches have been developed to monitor biodiversity in aquatic ecosystems. These enable access to taxonomic and genetic information from biological communities using DNA from environmental samples (e.g. water, biofilm, soil) and methods based on high-throughput sequencing technologies, such as DNA metabarcoding. Within the context of the Water Framework Directive (WFD), such approaches could be applied to assess Biological Quality Elements (BQE). These are used as indicators of the ecological status of aquatic ecosystems as part of national monitoring programs of the european network of 110,000 surface water monitoring sites with $79.5 \%$ rivers and $11 \%$ lake sites (Charles et al. 2020). A high-throughput method has the potential to increase our spatio-temporal monitoring capacity and to accelerate the transfer of information to water managers with the aim to increase protection of aquatic ecosystems.

Good progress has been made with developing DNA metabarcoding approaches for benthic diatom assemblages. Technological innovation and protocol optimization have allowed robust taxonomic (species) and genetic (OTU, ESV) information to be obtained from which diatom quality indices can be calculated to infer ecological status to rivers and lakes. Diatom DNA metabarcoding has been successfully applied for biomonitoring at the scale of national river monitoring networks in several countries around the world and can now be considered technically ready for routine application (e.g. Apothéloz-Perret-Gentil et al. 2017, Bailet et al. 2019, Mortágua et al. 2019, Vasselon et al. 2019, Kelly et al. 2020, Pérez-Burillo et al. 2020, Pissaridou et al. 2021). However, protocols and methods used by each laboratory still vary between and within countries, limiting their operational transferability and the ability to compare results. Thus, routine use of DNA metabarcoding for diatom biomonitoring requires standardization of all steps of the metabarcoding procedure, from the sampling to the final ecological status assessment in order to define good practices and standards.

Following previous initiatives which resulted in a CEN technical report for biofilm sampling and preservation (CEN 2018), a set of experiments was initiated during the DNAqua-Net WG2 diatom workshop (Cyprus, 2019) to focus on DNA extraction and PCR amplification steps in order to evaluate: i) the transferability and reproducibility of a protocol between 
different laboratories; ii) the variability introduced by different protocols currently applied by the scientific community. 19 participants from 14 countries performed DNA extraction and PCR amplification in parallel, using i) the same fixed protocol and ii) their own protocol. Experiments were performed by each participant on a set of standardized DNA and biofilm samples (river, lake, mock community). In order to specifically test the variability of DNA extraction and PCR amplification steps, all other steps of the metabarcoding process were fixed and the preparation of the Miseq sequencing was performed by only one laboratory. The variability within and between participants will be evaluated on DNA extracts quantity, taxonomic (genus, species) and genetic richness, community structure comparison and diatom quality index scores (IPS). We will also evaluate the variability introduced by different DNA extraction and PCR amplification protocols on diatom quality index scores and the final ecological status assessment. The results from this collaborative work will not serve to define "one protocol to rule them all", but will provide valuable information to define guidelines and minimum requirements that should be considered when performing diatom metabarcoding for biomonitoring.

\section{Keywords}

DNA Metabarcoding, Diatom, Intercalibration, Ring test

\section{Presenting author}

Valentin Vasselon

\section{Presented at}

1st DNAQUA International Conference (March 9-11, 2021)

\section{References}

- $\quad$ Apothéloz-Perret-Gentil L, Cordonier A, Straub F, Iseli J, Esling P, Pawlowski J (2017) Taxonomy-free molecular diatom index for high-throughput eDNA biomonitoring. Molecular Ecology Resources 17 (6): 1231-1242. https://doi.org/ 10.1111/1755-0998.12668

- Bailet B, Bouchez A, Franc A, Frigerio J, Keck F, Karjalainen S, Rimet F, Schneider S, Kahlert M (2019) Molecular versus morphological data for benthic diatoms biomonitoring in Northern Europe freshwater and consequences for ecological status. Metabarcoding and Metagenomics 3 https://doi.org/10.3897/mbmg.3.34002

- $\quad$ CEN (2018) Water quality. Technical report for the routine sampling of benthic diatoms from rivers and lakes adapted for metabarcoding analyses. PD CEN/TR 17245:2018.

- Charles D, Kelly M, Stevenson RJ, Poikane S, Theroux S, Zgrundo A, Cantonati M (2020) Benthic algae assessments in the EU and the US: Striving for consistency in the 
face of great ecological diversity. Ecological Indicators 121 https://doi.org/10.1016/ j.ecolind.2020.107082

- $\quad$ Kelly MG, Juggins S, Mann DG, Sato S, Glover R, Boonham N, Sapp M, Lewis E, Hany $\mathrm{U}$, Kille P, Jones T, Walsh K (2020) Development of a novel metric for evaluating diatom assemblages in rivers using DNA metabarcoding. Ecological Indicators $118 \mathrm{https}: / /$ doi.org/10.1016/j.ecolind.2020.106725

- $\quad$ Mortágua A, Vasselon V, Oliveira R, Elias C, Chardon C, Bouchez A, Rimet F, João Feio M, F.P. Almeida S (2019) Applicability of DNA metabarcoding approach in the bioassessment of Portuguese rivers using diatoms. Ecological Indicators $106 \mathrm{https}: / /$ doi.org/10.1016/i.ecolind.2019.105470

- Pérez-Burillo J, Trobajo R, Vasselon V, Rimet F, Bouchez A, Mann D (2020) Evaluation and sensitivity analysis of diatom DNA metabarcoding for WFD bioassessment of Mediterranean rivers. Science of The Total Environment 727 https://doi.org/10.1016/ j.scitotenv.2020.138445

- $\quad$ Pissaridou P, Vasselon V, Christou A, Chonova T, Papatheodoulou A, Drakou K, Tziortzis I, Dörflinger G, Rimet F, Bouchez A, Vasquez MI (2021) Cyprus' diatom diversity and the association of environmental and anthropogenic influences for ecological assessment of rivers using DNA metabarcoding. Chemosphere (129814). https://doi.org/10.1016/i.chemosphere.2021.129814

- Vasselon V, Rimet F, Domaizon I, Monnier O, Reyjol Y, Bouchez A (2019) Assessing pollution of aquatic environments with diatoms' DNA metabarcoding: experience and developments from France water framework directive networks. Metabarcoding and Metagenomics 3 https://doi.org/10.3897/mbmg.3.39646 